\title{
OF EMPTY THOUGHTS AND BLIND INTUITIONS KANT'S ANSWER TO MCDOWELL
}

\section{Günter ZÖLLER*}

\author{
"The history of philosophy \\ is the lingua franca \\ which makes communication \\ between philosophers ... possible." ${ }^{1}$
}

\begin{abstract}
A BSTRACT: This paper examines the relation between intuition and concept in Kant in light of J ohn McDowell's neo-Kantian position that intuitions are concept-laden. ${ }^{2}$ The focus is on Kant's tw ofold pronouncement that thoughts without content are empty and that intuitions without concepts are blind. I show that intuitions as singular representations are not instances of passive data intake but the result of synthetic unification of the given manifold of the senses by the pow er of the imagination under the guidance of the understanding. A gainst M CDowell I argue that the amenability of intuitions
\end{abstract}

${ }^{*}$ Professor of Philosophy at the University of M unich. He is a general editor of the Bavarian A cademy Edition of Fichte's Collected Works and a member of the Fichte Commission of the Bavarian Academy of Sciences and of the Kant Commission of the Berlin-Brandenburg Academy of Sciences. After studying at the University of Bonn (Dr. phil., 1982), the Ecole normale supérieure (Paris) and Brown University (Providence, USA) as a fellow of the German National Scholarship Foundation (1975-1982), he taught philosophy for sixteen years in the States, most of them at the University of lowa, where he also served as Chair of the Department of Philosophy.

${ }^{1}$ Wilfrid Sellars, Science, perception and reality, 1963, p. 1.

2 The Critique of pure reason will be cited by the original pagination of the second and first edition ("B" and "A," respectively), indicated in all modern English translations of the work. All other references to Kant's works are to Kant's gesammelte Schriften, ed. Royal Prussian Academy and its successor (Berlin, later Berlin/New York, 1900ff.) (henceforth "AA"), with the correspondence, vols. 10-13, cited after the second edition (1922). All translations are my own. 
to conceptual determination is not due some pre-existing, absolute conceptuality of the real but to the "work of the subject." ${ }^{3}$ On a more programmatic level, this paper seeks to demonstrate the limitations of a selective appropriation of Kant and the philosophical potential of a more comprehensive and thorough consideration of his work. Section 1 addresses the unique balance in Kant's philosophy between the work on particular problems and the orientation toward a systematic whole. Section 2 outlines M cDowell's take on the Kantian distinction betw een intuition and concept in the context of the Kant readings by Sellars and Strawson. Section 3 exposes M cDowell's relapse into the Myth of the Given. Section 4 proposes a reading of Kant's theoretical philosophy as an epistemology of metaphysical cognition. Section 5 details Kant's original account of sensible intuition in the InauguralDissertation of 1770. Section 6 presents the transition from the manifold of the senses to the synthesis in the imagination and the unification through the categories in the Critique of pure reason (1781 and 1787). Section 7 addresses Kant's formalism in epistemology and metaphysics.

KE YWORDS: Kant. J ohn M cDow ell. Intuition. Concept. M anifold. Synthetic unification.

\section{What is it about Kant?}

Two hundred years after his death on February 12, 1804, Immanuel Kant remains the most important modern philosopher. Since the mid-1780s his work has been the subject of hundreds of books and thousands of articles that have sought to state, understand, assess and, often, revise and amend his contributions to practically all fields of philosophy. M oreover, Kant has never only been the subject of scholarly work but the point of origin and inspiration for further philosophical work in its own right. From Fichte's and Hegel's speculative transformations through the epistemological appropriations by the M arburg and Southwest German neo-Kantians (Cohen, Natorp and Cassirer; Rickert and Windelband) and Husserl's Kantian turn to Heidegger's ontological Kant interpretation (and like-minded efforts on the part of Nic. Hartmann, H. Heimsoeth and G. Martin) and the clandestine Kantianism of the logical positivists (Carnap, Schlick) as well as the more recent analytic reading by Strawson and the communicative recasting in Continental pragmatism (K.-O. A pel, Habermas) - Kant has proved the fountainhead of most subsequent developments in philosophy, in addition to generating an entire industry of exegetical and interpretive scholarship along with journals, societies and prizes in his name.

The extent of the effective history of Kant's philosophy, unrivalled by that of any other philosopher, is due not only to the fact that Kant did original work in all of philosophy's main disciplines, from metaphysics and epistemology through philosophy of science, philosophy of history and aesthetics to ethics, philosophy of law and political philosophy. More

\footnotetext{
${ }^{3}$ AA 8:404, see note 87 .
} 
importantly, Kant's thinking has a unity of conception and execution that is both sufficiently complex to respect the genuine differences of the problems it addresses and seeks to solve, and that is sufficiently coherent to convey a sense of overall unity and of diligent subordination to an overriding purpose, how ever controversial the identification of that unifying purpose might be among Kant's readers and commentators.

Kant's merits as a philosopher are in no small measure determined by the extraordinary combination that characterizes his work: the overall, systematic architecture of the procedures and positions he follows and develops goes together with intricately detailed argumentative work. The systematic conception does not get lost in the doctrinal details of its execution, nor are the particularities of his philosophical labor overshadowed or manipulated by the overriding concerns. As a result of this genuine balance of the systematic whole with the particular part, dealing with key problems and doctrines in Kant typically involves a dual enterprise: encountering an original, challenging or puzzling (as the case may be) micro theory to be grasped and assessed, and becoming immersed in the wider significance of the particular problem and solution in the context of a more comprehensive macro theory, with the latter ideally extending to encompass all of philosophy. Kant's continuing attractiveness to other philosophers of the first order is no doubt due to this dual feature of combing, or better yet, of integrating the whole of philosophy and its parts in a thoroughgoing manner. $\mathrm{He}$ is at once the most systematic thinker when dealing with particular problems in philosophy and the most problem-oriented thinker when addressing systematic issues.

\section{From Köngisberg to Pittsburgh}

A prime case of Kant's intriguing ability to keep both the trees and the forest in view is his treatment of the relation betw een concept and intuition in the account of the possibility of objectively valid cognition (knowledge) in the Critique of pure reason. At issue are the generically different but functionally coordinated roles played by the deliverances of each of the two basic "stems" (Stämme) of cognition, viz., intuitions conveyed by "sensibility" (Sinnlichkeit) and concepts delivered by the "understanding" (Verstand). The particular problem Kant faces at this point in the first Critique is how cognition can have a material basis in the input of the senses and yet be amenable to further determination by non-sensory, intellectual powers of the mind without loosing its cognitive grip on things and turning into a merefigment of the mind. The larger issue behind Kant's quest for the transition from the aesthetic to the logical conditions of possible cognition is "our" dual nature 
as sensory-cum-rational subjects of cognition (knowers), and as equally dually constituted subjects of volition (doers) at that. On the one hand, we passively undergo the influence exercised on our "receptivity" (Rezeptivität) and to that extent are an integral part of the order of nature. On the other hand, we actively respond to the sensory input by means of our "spontaneity" (Spontaneität), take up the sensory data into higher-level cognitions and to that extent transcend that which is "given" (gegeben) toward that which is "thought" (gedacht). ${ }^{5}$

From early on through the present time Kant's dualism of intuition and concept, which is at its root a dualism of sense and intellect, has been the subject of emendations and revisions. To many it has seemed that Kant could not have it both ways, viz., distinguish radically between intuiting and thinking and claim their possible, indeed necessary cooperation in the business of warranted cognition. The typical strategy for the purported clearing up of the basic inconsistency in Kant's account of knowledge has been the one-sided reduction of the duality of intuition and concept (or thought) to an encompassing monistic conception of thought or intuition, respectively. The one-sided reduction of intuition to thought goes back to Hegel's speculative interpretation of the Critique of pure reason in Faith and knowledge (1802), where intuition and thinking are said to pertain not to "particular isolated faculties" (besondere isolirte Vermögen) but to an underlying encompassing "understanding" (Verstand) and its non-sensory or "intellectual intuition" (intellectuelleAnschauung). ${ }^{4}$ The reverse reduction has been championed by the early Heidegger's finitist reading of Kant as a proto-existential ontologist in Kant and the problem of metaphysics (1929), in which thinking is treated as completely subordinated to the originary grasp of things by means of their "presentment" (Dargebot) in intuition. The exact counterpart to Hegel's reductive "intellectual intuition" is Heidegger's equally anti-dualist "thinking intuition" (denkende Anschauung). ${ }^{5}$

More recently, the Hegelian revision of Kant's fundamental distinction between intuition and concept has found renewed attention in the work of J ohn M cDowell - first, and more programmatically, in McDowell's M ind and world $(1994)^{7}$ and then, with more exegetical and interpretive detail, in his

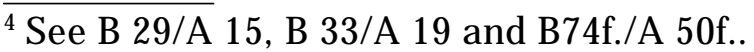

${ }^{5}$ Georg Wilhelm Friedrich Hegel, J enaeer Kritische Schriften, ed. Hartmut Büchner and Otto Pöggeler (Hamburg: Felix Meiner, 1968), p. 327.

${ }^{6}$ Martin Heidegger, Kant und das Problem der Metaphysik. Fourth, enlarged edition (Frankfurt/M.: Vittorio Klostermann, 1973), p. 59 and 27, respectively.

${ }^{7}$ With a New Introduction (Cambridge, Mass: Harvard University Press, 1996) (henceforth "MaW").
} 
1997 Woodbridge Lectures at Columbia University, "Having the World in View: Sellars, Kant, and Intentionality". ${ }^{8}$ As the subtitle of the latter work indicates and as is clearly stated in both works, M cDowell's interpretation of Kant has developed under the influence of the neo-Kantian philosophy of mind of the late Wilfrid Sellars (1912-1989), especially the latter's seminal essay, "Empiricism and the Philosophy of M ind" (1956) ${ }^{9}$ and his book, Science and metaphysics. Variations on kantian themes (1963). ${ }^{10}$ But while drawing and building on Sellars, M cDowell departs from Sellars's reading of Kant in important ways, and this especially in the Woodbridge Lectures. ${ }^{11}$ In fact, rereading $M$ ind and world in light of the further developments of M cDowell's Kantianism and Kant interpretation in the Woodbridge Lectures makes it clear that M cDowell's Kant is at bottom the Kant of his Oxford mentor, Peter Strawson, ${ }^{12}$ and not that of his former Pittsburgh colleague, Wilfrid Sellars. Like Strawson, and unlike Sellars, M cDowell eschews Kant's (transcendental) idealism in favor of a (transcendental) realist conception of experience and its objects. Like Strawson, and again unlike Sellars, he sets aside Kant's metaphysics of subjectivity (or the "metaphysics of epistemology," to use Sellars's phrase) ${ }^{13}$ in favor of a conceptual analysis of the implications of the empirical cognition of objects.

To be sure, both McDowell and Sellars pursue the project of integrating the Kantian mind into the Kantian world, of embedding the subject of cognition into the world it cognizes and thus of integrating our vantage point on the world into our picture of the world. And Sellars and M cDowell agree that this integration of subjectivity, which both regard as in the main characterized by intentionality, is not to be achieved by a reduction of mind to matter but calls for the preservation of the mind's genuine area, the "logical space of reasons," as opposed to the "logical space of nature" (Sellars). ${ }^{14}$ Hence the project inaugurated and undertaken by Sellars and taken up by $\mathrm{M}$ cDowell calls for a non-reductive integration of mind and nature (or mind and world, in the phrase of McDowell's book title) that is as much a naturalization of the mind as it is an idealization of nature or the world.

\footnotetext{
${ }^{8}$ The J ournal of Philosophy, v. 95, n. 9, p. 431-491, Sept. 1998 (henceforth "HaWiV").

${ }^{9}$ Reprinted in Wilfrid Sellars, Science, perception and reality, p. 127-196.

10 (New York: The Humanities Press, 1968).

${ }^{11}$ See MaW, ix, xivff.; HaWiv, 431.

12 See MaW, viii.

${ }^{13}$ See The Metaphysics of epistemology. Lectures by Wilfrid Sellars, ed. Pedro Amaral (Atascadero, CA: Ridgeview Publishing, 1989).

14 "Empiricism and the philosophy of mind," p. 161.
} 
In pursuing this project Sellars finds it necessary to follow Kant into providing a transcendental-idealist account that dilutes the apparently robust objects of experience into products of non-empirical engagements between the mind's depth structure and the depth structure of the world. In the process, Sellars identifies Kant's things in themselves with the micro-features of natural-scientific theorizing and attributes to Kant a position of scientific realism. By contrast, M cDowell effectively collapses the Kantian distinction between things in themselves and empirical objects and argues for the irreducible status of middle-sized things in space and time. Moreover, according to $\mathrm{M}$ cDowell, those ordinary entities present themselves in intuition always already exhibiting the very conceptual features which provide the full-fledged, preformed basis for the subsequent formation of judgments about those objects and their features. In a move that has a decidedly Hegelian ring to it, M cDowell rejects the orthodox Kantian conception of the discrepancy between the things themselves and the cognitive reach of our concepts. Instead M cDowell maintains what he calls "the unboundedness of the conceptual"15 and the coextensionality of the conceptual and the real. On McDowell's understanding, any other account of the relation between concept (or cognition) and the real imputes inscrutability to the latter, infects the former with skeptical reservations and renders impossible the philosophical project of a unified account of mind and world that M cDowell takes over from Sellars.

The length to which philosophers from Hegel to M cDowell have gone in revising the dualist account of cognition developed by Kant attests to the urgency of the problem bequeathed by him. At issue are not only the possibility and the form of epistemology but also, in line with Kant's vaulting ambition, the image of the world and our place in it implied by the dualisms of sensibility and understanding, of receptivity and spontaneity, of intuition and concept. A closer look at Kant's own position on this central matter of modern philosophy, effectuated in the light of M cDowell's recent proposals and in response to them, is therefore not merely a matter of Kant scholarship, of setting the record straight, based on acquaintance with the larger corpus of Kant's texts and with the philosophical development from which they resulted and which they reflect as well as presuppose. Such a return to Kant also has the potential of drawing renewed attention to the overall structure and design of Kant's transcendental philosophy, especially its ingenious linkage of epistemological and metaphysical concerns, which is apt at putting in perspective current work in a similar vein.

${ }^{15} \mathrm{MaW}, 24 \mathrm{ff}$. 


\section{Remythologizing the Given}

At the center of each of M cDow ell's two sequentially organized readings of Kant, in M ind and world and the Woodbridge Lectures, stands a key quote from the first Critique that serves as the abbreviation of the main problem under discussion as well as the indication of Kant's and M CDowell's solution to the problem. In M ind and world the central quotation is "Kant's remark 'Thoughts without content are empty'," supplemented by "the other half of Kant's remark: 'intuitions without concepts are blind'." ${ }^{16}$ In the Woodbridge Lectures the central quotation is the key phrase from the "'Clue to the Discovery of All Pure Concepts of the Understanding' (in the so-called 'M etaphysical Deduction'), where Kant says: 'The same function which gives unity to the various representations in a judgment also gives unity to the mere synthesis of various representations in an intuition'."17 Since $M c D o w e l l ' s$ reading of the second quotation turns on his understanding of the first one, it is indicated to address them in order and focus on the latter.

McDowell turns to Kant's tw ofold remark on the avoidance of empty thoughts and blind intuitions in the context of Donald Davidson's distinction between conceptual scheme and content. ${ }^{18} \mathrm{McD}$ cowell stresses that the content opposed to "scheme" or "conceptual schema" by Davidson cannot be a logical entity such as a proposition or a thought, since the latter is not opposed to a conceptual scheme or, more generally, the conceptual, but forms part of it. Therefore M cDowell considers himself entitled to rule out that the content referred to by Davidson and Kant is intentional content or, as he puts it "representational content." According to M cDowell, Kant's assertion that concepts without intuition are empty is not to be read as the tautological statement that a thought that has no representational content, and hence is not about anything, is about nothing or is empty. Rather, on McDowell's view, Kant's statement that thoughts without content are empty is an informative, philosophically illuminating remark that specifies what is lacking in a thought that, while being a thought, and hence also possessing representational content, is lacking something else, viz., "connection with experiential intake"19 or empirical grounding. The non-representational content possibly lacking in the concept is thus the "empirical content." 20

\footnotetext{
${ }^{16} \mathrm{MaW}, 3 f$.; the quotation from Kant is at B 75/A 51.

17 HaWiV, 457; the quotation from Kant is at B 104f./A 79.

18 "On the very idea of a conceptual scheme". In: DA VIDSON, Donald. Inquiries into truth and interpretation, 1984, p. 183-198.

${ }^{19} \mathrm{MaW}, 4$.

${ }^{20} \mathrm{MaW}, 5$. See also the use of the phrases, "uninterpreted content" and "empirical content," in Davidson, "On the very idea of a conceptual scheme," p. 187 and 189, respectively.
} 
Moreover, McDowell identifies the basis in experience that is required by the dualism of the conceptual and the contentual with what the empiricist tradition recognizes as the "the Given," and typically specifies as impressions or sense data. Finally, he maps the distinction of conceptual scheme and content in Davidson on Kant's distinction between concept and intuition, thereby glossing "content" in Kant as empirical intuition.

But just as little as Davidson buys into the distinction between conceptual scheme and empirical content, does M cDowell accept the duality of concept and (empirical) intuition he attributes to Kant. Following Sellars's critique of the "Myth of the Given," 21 McDowell rejects the notion that an empirical datum as such could exercise an epistemological function in validating otherwise empty concepts. For Sellars as for M cDowell the logical space of warrants for cognitive claims does not include psycho-physiological items and their natural (causal) interaction or action upon some perceiver. The justificatory enterprise of cognition allows only for logical relations, such as those of implication or contradiction, between concepts as the only denizens of the logical space of reasons. Empirical content, such as Kantian empirical intuitions, construed as extra-conceptual occurrences in the process of cognition, are therefore not able to accomplish the justificatory function assigned to them by Kant. The given as the terminus of the chain of epistemological moves of authentification, running down from highly abstract concepts to ultimate justifiers in the form of rock bottom reality, turns out to be a myth, shared by the empiricists and by Kant, as the latter is construed by McDowell.

Yet the obvious alternative to the concept-content dualism, viz., innerconceptual coherentism, as embraced by Davidson, is equally unappealing to McDowell. He rejects giving up on the idea of extra-conceptual constraints on cognition. Instead he returns to Kant's "original thought," this time stressing the "co-operation" between sensibility and understanding, rather than their juxtaposition. ${ }^{22}$ M CDowell's proposed Kantian way out of the alternative of incoherent empiricist foundationalism and unfounded conceptualist coherentism is the idea that "conceptual capacities are drawn on in receptivity." ${ }^{23}$ For M cDowell, receptivity, along with its deliverances, does not make on its own a contribution to cognition but only in connection with concepts. There is not, first of all and by itself, receptivity and its yield, which would then be acted upon by spontaneity and its concepts. Rather receptivity

\footnotetext{
${ }^{21}$ See Sellars, "Empiricism and the philosophy of mind."

$22 \mathrm{MaW}, 9$.

${ }^{23}$ MaW, 9 (McDowell's emphasis).
} 
only comes into play imbued with concepts or, at least, with conceptual capacities. Accordingly, M cDowell understands intuition in Kant "not as a bare getting of an extra-conceptual Given, but as a kind of occurrence or state that already has conceptual content." 24 Thus McDowell countenances a passive undergoing of sensory input at the level of intuition involving concepts but not involving their employment in spontaneously formed judgments.

McDowell's term for such a full-fledged cognition that is both passive and concept-laden, is "experiential intake" or, in short, "experience."25 According to M cDowell, in experience of this sort "one takes in ... that things are thus and so." 26 On this account, the conceptual determinations that may serve subsequently in a spontaneously formed judgment about some object being such and such, are already present in the initial encounter of that object solely by means of intuition. Moreover, the presence of those pre-judgmental but already conceptual features in intuition is not due to some other, perhaps clandestine activity on the part of the intuiting subject. Rather the conceptual features simply are present in intuition, as a matter of fact; they present themselves in intuition, without our doing and prior to our doing. On McDowell's understanding of the matter, then, what is given in intuition is not some pre-conceptual "bare" impression but a conceptually structured fact, formally expressible by phrases such as "that things are thus and thus." This is indeed, as McDowell claims, "a different notion of givenness." 27 What is "given" in a McDowellian intuition is already of a conceptual nature and hence pertains to the logical space of reasons. There is no longer, as in the empiricist idea of the bare sensory given, a discrepancy between the space of the conceptual and that of the real.

The notion that intuition already presents us with conceptual data also informs M cDowell's reading of the second quotation from Kant cited earlier, which had already figured prominently in Sellars, ${ }^{28}$ on the identity of the function providing unity in judgment with that providing unity in intuition. For M CDowell this identity statement of Kant's confirms that what is rendered explicit at the level of freely formed judgments is already implicitly present ("given") in the deliverances of intuition, which can be said to have their own unity, which is pre-judgmental but not pre-conceptual. (A closer look at the systematic context of Kant's remark will show that the latter's point is not the conceptual unity to be found in intuition but the unity brought to intuitions,

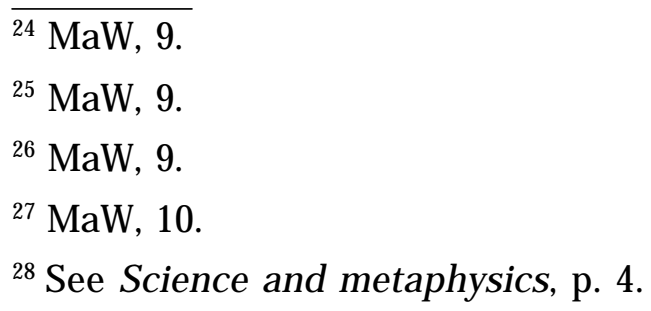


which as such do not possess unity but obtain it from outside of them, viz., through the power of the imagination under the guidance of the understanding.)

McDowell's strategy in dealing with the Scylla of the mythical Given and the Charybdis of coherentism has been to move the ultimate, most basic warrants of epistemic claims from outside the logical space of reasons, from where they could not exert a justificatory function, to inside the sphere of rational relations. But there is a price to pay for this seemingly elegant solution. By internalizing Kantian intuitions into the space of the conceptual, M cDow ell lapses nolens volens into a version of coherentism. M ore precisely, the constraint provided by conceptually determined intuition is an internal constraint of concepts embedded in intuition on the explicit deployment of these concepts in the formation of judgments. While M cDow ell has managed to preserve the constraint factor within the conceptual sphere by having the conceptual in intuition constrain the conceptual in judgment, he has lost the constraint on the conceptual. By effectively giving up the Kantian dualism of intuition and concept, McDowell has reverted (or progressed, as one's view point may have it) to a Hegelian monism of logical concepts or a logical idealism that defends the conceptuality of the real.

At this point, M CDow ell's epistemology risks turning into an ontology of objective conceptual data. The kind of Given envisioned by McDowell involves a new "M yth about the Given," one about the alleged givennesss of concepts. But while it is quite obvious that M cDowell's position about the conceptual nature of intuition is not Kant's position, it remains to investigate whether and how Kant's dualism of intuition and concept manages to avoid the dual pitfall of an empiricist pseudo-epistemological foundationalism that conflates causation with justification and an idealist pseudo-ontological idealism that confuses consistency with truth. The key elements of an answer to this vexing question lie in the status and function of intuition in Kant.

\section{Back to Kant}

Neither on his long way toward the Critique of Pure Reason nor in that work itself did Kant set out to provide a theory of empirical cognition. What McDowell, and not a few readers before him, see as the center of Kant's concerns is rather a byproduct of Kant's actual key project of reforming metaphysics, or, to put the matter in the cognitivist language favored by McDowell, of the epistemology of metaphysical cognition, ${ }^{29}$ as summarized

\footnotetext{
${ }^{29}$ On this characterization of Kant's critical project, see my "Kant on the Generation of Metaphysical Knowledge," in Kant: Analysen - Probleme - Kritik, ed. Hariolf Oberer and Gerhard Seel (Würzburg: Königshausen und Neumann, 1988), p. 71-90.
} 
the leading question of the Prolegomena and of the second edition of the first Critique, "How are synthetic judgments priori possible?" 30 To be sure, Kant's elaborate answer to this question involves substantial insights into the nature of empirical cognition or, technically put, into synthetic cognition a posteriori. But the latter type of cognition is not elucidated on its own and with the degree of attention typical for modern work in epistemology. In fact modern epistemology is largely a post-Kantian project, building on Kant's work by extending it into areas and directions (cognitive psychology, logic of belief) that were not at the forefront of Kant's central concern in theoretical philosophy, namely with the possibility of metaphysics. ${ }^{31}$

Moreover, even when addressing empirical cognition in the first Critique, Kant focuses on what is non-empirical or "pure" in and about empirical cognition. What emerges about empirical cognition in the first $C$ ritique is a deep structure that underlies all empirical cognition and that presents itself only in the philosophical meta-cognition concerning the non-empirical conditions of empirical cognition. Still the complex interplay between the empirical and the non-empirical, or in Kantian terms: between experience and the conditions of its possibility, is not a side issue in Kant but constitutes his very answer to the problem of metaphysics or the question concerning metaphysical cognition. M etaphysical cognition, insofar as the latter is "able to present itself as science" (to use the phrase from the title of the Prolegomena), is not the cognition of some transempirical or supersensory world and its putative objects (God, soul, freedom) but the cognition of the complete set of conditions that are necessary for the very possibility of empirical cognition or of experience..$^{32}$

\footnotetext{
${ }^{30}$ See AA 4:276 and B B19. On the origin of this particular formulation of the key problem of Kant's theoretical philosophy, see my "Editor's Introduction," in Immanuel Kant, Prolegomena to any future metaphysics that will be able to present itself as science, ed. Günter Zöller (Oxford: Oxford University Press, 2004), 21ff.

${ }^{31}$ On the post-Kantian history of epistemology, see Richard Rorty, Philosophy and the mirror of nature (Princeton: Princeton University Press, 1979), 131ff. and Klaus-Christian Köhnke, Entstehung und Aufstieg des Neukantianismus. Die deutsche Universitätsphilosophie zwischen Idealismus und Positivismus (Frankfurt/M., 1986).

32 For a closer analysis of the metaphysic compatible with Kant's critical philosophy, see my series of essays, "Pax Kantiana. Kant e la pace perpetua in filosofia," in Filosofia e guerra nell'età dell'idealismo tedesco, ed. Gaetano Rametta (Franco Angeli: Milano, 2003), p. 51-64, "In der Begrenzung zeigt sich der Meister. Der metaphysische Minimalismus der Kritik der reinen Vernunft," forthcoming in Kants Kritik der M etaphysik. Studien zur Transzendentalen Dialektik der "Kritik der reinen Vernunft". Neue Studien zur Philosophie. v. 19, ed. K. Cramer and J. Stolzenberg (Göttingen: Vandenhoek und Ruprecht, 2004) and "M etaphysik nach der Metaphysik. Die limitative Konzeption der Ersten Philosophie bei Kant," forthcoming in a volume on metaphysics in a postmetaphysical age, edited by Karin Gloy.
} 
The negative, restrictive side of this revolutionary reorientation of metaphysics from the transcendence of the empirical to its non-empirical, "transcendental" grounding is the limitation of non-empirical cognition, more precisely of non-empirical theoretical, object-determining cognition (as opposed to practical, will-determining cognition involved in moral philosophy) to possible experience and to the objects of possible experience. M etaphysics as theoretical cognition ("science") is the metaphysics of experience. But there is also a positive, enriching side to Kant's new metaphysics, viz., the insight that experience cannot take care of itself but involves structures and strictures that are non-empirical and that imply the presence of non-empirical or metaphysical elements in experience itself. A philosophically satisfactory account of experience has to be metaphysics of experience.

The metaphysical secret of empirical cognition, viz., that there is more to experience than can be the object of experience, is also the key to Kant's puzzling remarks about thoughts being possibly empty and intuitions being possibly blind. At the surface level the remark addresses the requirement of a match or a correspondence between the two elements involved in (theoretical) cognition, viz., intuition and concept. An intuition and a concept belong to each other, complement each other and constitute a cognition in the full-fledged sense if what is sensorily given in intuition provides the material realization for what is thought in the concept, and if, vice versa, that which is being thought by the concept transforms the sensory content of an intuition into the cognition of an object. In such a situation of match the intuition and the thought involved seem to be the intuition and the concept, respectively, of the same object, an object that is given in one case and thought in the other case. But any such talk of presupposed objects and their alternative modes of presence to the mind (as intuition and as concept, respectively) suggests a realist ontology which Kant does not only not take for granted but considers very much in need of examination and revision.

Kant's philosophical concern is not with the de facto match between the intuition of an object and the concept of that object but with the question how there can be such a situation of match at all, especially considering the radically different nature of intuition and concept, due to their origin in two entirely different cognitive capabilities, viz. sensibility and the understanding. In advance of any particular match of some intuition and some concept with regard to some object, there is the fundamental philosophical issue of how intuitions and concepts can agree in the first place. To take it for granted that they are able to do so, as McDowell does, underestimates Kant's philosophical amazement about concepts and intuitions and the theoretical urgency of the problem that their possible relation of match or agreement possesses. What McDowell treats as the solution to the problem about 
intuition and concept - that the two make use of each other by one contributing to the other what the one possesses and what the other is lacking - is the very problem Kant sets out to resolve in the sections following this opening remark early on in the Transcendental Logic of the first Critique. In particular, he goes on to investigate how the "pure concepts of the understanding or categories" (reine Verstandesbegriffe oder Kategorien) ${ }^{33}$ can have any bearing on what is given in intuition or how the latter can undergo the former's shaping influence. This is exactly the problem of the transcendental deduction of the categories and the associated investigations of the relation between the unity in intuitions and the unity in judgments (M etaphysical Deduction ${ }^{34}$ ), of the mediation between category and pure intuition (Schematism of the Pure Concepts of the Understanding) and of the supreme synthetic cognitions a priori yielded by the match of categories and pure intuitions (Principles of the Pure Understanding). The entire extended argument of the Transcendental A nalytic is required because in and of themselves concepts and intuitions have nothing in common, except their formal status as "representations" Norstellungen) in the mind in a generic, undifferentiated sense unsuitable for assessing their respective and collaborative epistemological functions.

It should be stressed that Kant's problem regarding intuition and concept is not limited to the relation between pure concepts and pure intuitions. It also presents itself for empirical intuitions and empirical concepts. After all, on Kant's account, the transcendental account of the categories and the pure manifold of the senses does not relate to some strange and unusual kind of cognition unrelated to ordinary knowledge but represents, in the artificial isolation of philosophical theorizing, the universal requirements of empirical cognition and its objects. However, the philosophical problem about empirical cognition is not that of the match of empirical intuition and empirical concept. $M c D o w e l l$ is right to assert that empirical intuition is to be considered as already standing in a relation of match to possible empirical concepts - just as empirical concepts must be considered as already standing in a relation of match to possible empirical intuitions. Rather the philosophical problem about empirical cognition is how to bring together the formal, non-empirical structures underlying all experience (based on pure concepts and pure intuitions and objectified in universal laws of nature) with materially concrete sensory data. This problem of integrating sheer data into both the forms of intuiting and the forms of thinking still figures large in Sellars' appropriation of Kant but not in

\footnotetext{
$\overline{33}$ See B 102/A 76.

${ }^{34}$ The term "metaphysical deduction," designating the derivation of the categories from the forms of judgment, first occurs in the second edition of the first Critique (B 159).
} 
M cDowell's, for whom the given does not consist of raw data to be taken up by intuitive as well as intellectual forms of cognition but of already conceptually informed intuitions. Nor is there in M cDowell's Strawsonian rather than Sellarsian Kant room for the dynamics of the universal but subjective cognitive forms enabling the formation of objectively valid cognitions. Yet without the latter, the match of intuition and concept, whether in its generic form or as the agreement between empirical intuitions and empirical concepts or as the match of pure intuitions and pure concepts, remains a brute fact, unexplained and in principle subject to falsification. Faced with the skeptical implications of such an epistemology of conceptual facts, Kant would have stressed the merits of his own decidedly non-empirical ("metaphysical") account of cognition.

\section{The Discovery of Pure Intuition}

Kant's differentiation between intuition and concept is the result of his long-standing investigations into the possibility of metaphysical cognition, and specifically into the possibility of metaphysical cognition about the nature and constitution of the world (cosmology). The precise point of origin for Kant's opposing intuitions to concepts is the novel theory of space and time developed by Kant in the late 1760s and first presented in published form in the Inaugural-Dissertation of 1770 , On the form and grounds of the sensible and intelligible world. ${ }^{35}$ In this work Kant takes up the traditional distinction between the "world of sense" (mundus sensibilis) and "world of the understanding" (mundus intelligibilis), which can be dated back to Plato's distinction between the Forms and the appearances and which had received renewed attention through Leibniz's distinction between the "realm of nature" and the "realm of grace." 36 But unlike the Platonic (or rather the neo-Platonic) tradition, ${ }^{37}$ which had viewed the world of sense as

\footnotetext{
35 See AA 2:385-419, esp. 398-406. The term "principia" in the work's Latin title (De mundi sensibilis atque intelligibilis forma et principiis) means "grounds" (German Gründe) and not "basic propositions" (German Grundsätze), and should therefore perhaps not be rendered as "principles." A first step toward Kant's novel theory of space is taken in the essay, Concerning the Ultimate Ground of the Differentiation of Directions in Space, from 1768; see AA 2: 375-384. Modern English translations of these works, cued to the pagination of the Academy Edition cited in this paper, are to found in Immanuel Kant, Theoretical philosophy 1755-1770, ed. David Walford and Ralf Meerbote (Cambridge: Cambridge University Press, 1992), p. 373-416 and 361-372.

${ }^{36}$ See, e.g., "Principles of Nature and Grace," in G. W. Leibniz, Philosophical essays, ed. Roger Ariew and Daniel Garber (Indianapolis and Cambridge: Hackett, 1989), p. 206-213.

37 On Kant's attribution of intuitus to Plato see. e.g., Reflexion 4446 (AA 17: 554; approximately 1772): "Ideas in Plato are intuitus." (Ideen sind beym Plato intutitus.).
} 
ontologically and epistemologically inferior to the world of the understanding, Kant argues for the genuine status of both worlds and of our cognition of them. In so doing, he replaces the rationalist assessment of cognition by the senses, as lacking the clarity and distinctness available to cognition by the intellect, with an alternative account that recognizes the autonomous nature of both kinds of cognition and of the two orders of things or worlds correlated with them. For Kant the world of sense and the world of the intellect each have their own formal structures and laws, and the attempt to blur the distinction between the two epistemologies and ontologies results in the self-contradictory claims that are the antecedents of the A ntinomy of Pure Reason in the Critique of pure reason.

The term "intuition" (intuitus) first occurs in the Inaugural-Dissertation of 1770 in the negative statement that the human being does not have at its disposition an intuition of things intellectual. ${ }^{38}$ The intellect's intuition, or intellectual intuition, mentioned by Kant would be the intellect's ability to grasp things "immediately" and "in their singularity" (immediate, ut singulare), hence without the employment of other means of cognition and without cognitively relating that which is being intuited to anything else. On Kant's analysis, the human intellect or understanding does not grasp things intuitively, or immediately and in their singularity, but only discursively (discursive), or by means of "general concepts " (conceptus generales) that do not address the object in its singularity but in terms of what it (possibly) shares with other objects.

But while the human being does not possess an intellect that intuits, it yet has another kind of intuition at its disposal, one that represents a mode of cognition different both from the discursive cognition of our intellect and the intuitive cognition of a possible non-human (or rather superhuman, divine) intellect. According to Kant, this "human intuition" (intuitus humanus) ${ }^{39}$ is like intellectual intuition to the extent that it grasps its object in an immediate manner, without the involvement of any other mode of cognition, and that it takes cognizance of this object in its singularity, as a unique entity that does not come into view as being like (or unlike) any other possible object. Yet human intuition is unlike intellectual intuition to the extent that is does not actively give itself its object - like the divine intellect in which cognition and creation coincide -, but must have its object given to it. Human intuition is "passive" (passivus). ${ }^{40}$ It involves the mind's capacity to undergo cognitive

${ }^{38}$ AA 2: 396: "Intellectualium non datur (homini) intuitus." The Kantian terms introduced in this paragraph are all taken from AA 2: $396 f$.

${ }^{39}$ AA 2:396.

${ }^{40}$ A A 2: 397. 
influence, which Kant terms "sensibility" (Sinnlichkeit) ${ }^{41}$ in view of the fact that the material data to enter into human intuition are provided by the senses. Accordingly, human intuition can also be characterized as "sensible intuition" (intuitus sensualis), ${ }^{42}$ which means an intuition - or a passive, immediate and singular mode of cognition - that is based on the conveyances of the senses, termed "sensation" (sensatio). ${ }^{43}$

It is important to stress the difference Kant sees between sensation as the material involved in sensible intuition and sensible intuition as the medium or dimension, or better yet: the cognitive form, into which sensation is taken up or incorporated. On Kant's analysis, the nature of human, sensible intuition qua intuition, as described above (immediateness, singularity), does not belong to the deliverances of the senses as such but only to the form under which they enter into the mind's cognitive apparatus. For Kant, this form of sensible intuition is the double form of space and time, in which all sensory date are contained. But space and time are not only the forms of sensibility. First and foremost they are themselves intuitions. To be sure, as forms for all "later" filling by sensory material, space and time themselves are not intuitions filled with sensory matter. Rather they are a case of "pure intuition" (intuitus purus). ${ }^{44}$ According to Kant, space and time as pure sensory intuitions possess the following properties: they are given to the mind (rather than being produced by the mind, as concepts are); they are singular (rather than universal, as concepts are); they are totalities preceding any part of time or space - any stretch of time and any region of space (rather than parts preceding a whole, as in the case of the relations based on concepts). 45

Hence the difference between pure intuitions and concepts in Kant turns on the different mereology of the two kinds of cognition and their respective objects. In the pure intuition of time and space the intuited is given as an infinite, all-encompassing whole, such that any temporal or spatial part is but a limitation of the original pure intuition of time and space. By contrast, in the case of concepts regarding the formal structure of the world (cosmological concepts) the whole succeeds the parts out of which it is made up. Moreover, concepts may contain other cognitions, such as other

\footnotetext{
41 AA 2: 392.

42 AA 2: 403. see my Editor's Introduction in Kant, Prolegomena, 51.

${ }^{44}$ AA 2: 400 (regarding time) and 402 (regarding space).

${ }^{45}$ See AA 2: 398ff., esp. $405 f$.
}

${ }^{43} \mathrm{AA}$ 2: 392. On the inexactitude involved in the standard rendering of Kant's Latin term, "sensitivus," and its German equivalent, "sinnlich," as "sensible," rather than "sensory," 
concepts, under themselves, but they do not contain those lower concepts in themselves; rather higher concepts are contained by lower concepts. By contrast, time and space as pure intuitions contain all possible times and spaces in them, and as infinite singular wholes they do not have features in common with anything outside them. Thus for Kant entirely different partwhole relations obtain in intuitions, specifically in pure intuitions, on the one hand, and in concepts, on the other hand.

To be sure, the givenness of time and space as infinite intuitions cannot be understood on the model of the givenness of sensations, as coming to us from outside and as affecting us contingently. Rather to call time and space "given" is to address the fundamental fact that prior to and independent of all sensory data we may receive, there is present in our mind a comprehensive structure ready to be filled with material to be provided by the senses such that all possible sensible cognition will be contained in this structure and marked by its formal features. One might call the mode of givenness peculiar to pure intuitions their pre-givenness (Vorgegebenheit). Kant goes so far as to liken the infinite pure intuition of time and space to divine intellectual intuition because in both cases there is an immediate and complete grasp of some whole - all of creation in one case and all of time and space in the other case. ${ }^{46}$ But Kant is also careful not to consider the givenness (or pregivenness) of pure intuition a case of something lying all ready in the mind or being "inborn" (innatus). Instead he considers time and space as "acquired" (acquisitus); to be sure, not as acquired from the senses and particular sensations, but as acquired internally from the immanent law of the universal human cognitive constitution that shapes the taking-in of sensory data. ${ }^{47}$ Space and time in their original nature as infinite intuitions are the basic modes of having sensory data enter into the process of cognition, viz., as temporally arrayed and spatially located in two infinite continua.

In historical terms, Kant's theory of time and space as forms of intuition and as pure intuitions brings together key elements of the earlier accounts of space and time provided by Newton and Leibniz. While the infinite magnitude of time and space in Kant retains elements of the Newtonian conception of space as an absolute entity or a cosmic container modeled on God's presence throughout the universe, their character as subjective forms of all sensory cognition is indebted to the Leibnizian conception of the phenomenal nature of time and space as the two orders that things take on under conditions of sensory cognition. Unlike Newton, Kant defends the

\footnotetext{
$\overline{46}$ See AA 2: 405 (secundum exemplar intuitus sensitivi).

47 See AA 2: 406.
} 
subjective origin of time and space. Unlike Leibniz he maintains their a priori character, their preceding rather than succeeding the things of which they are the ordering forms. And unlike either Newton or Leibniz Kant maintains that time and space are pure sensible intuitions. The very notion of a pure sensible intuition as the cognitive form of given infinite wholes is entirely original to Kant and underlies not only his account of space and time in the first Critique but also its mature theory about the cooperative relation between intuition and concept.

\section{From Manifold to Synthesis and Unity}

All the main features of the account of time and space to be found in the Inaugural-Dissertation, centered around the double notion of time and space as forms of intuition and as pure intuitions, are taken over in the Transcendental Aesthetic of the first Critique. ${ }^{48}$ How ever, the later work adds an important systematic concern with the transition from pure intuition to pure concept, addressed throughout the Transcendental Logic, more precisely in its analytic part (Transcendental Analytic). Hence the further development of Kant's thinking about intuitions and concepts that manifests itself in the first Critique deals not with the conveyances of sensibility as such but with their further non-sensory treatment by other powers of the mind. In particular, Kant contrasts the non-structured manner in which representations present themselves to the mind at the strictly sensory level with the form and structure introduced into spatial and temporal data by non-sensory means. The term from the Inaugural-Dissertation designating the plenary but inarticulated sum-total of presentments in intuition as such, "varia," is rendered in the first Critique as "manifold" (Mannigfaltiges) and strictly distinguished from any order or structure brought to the manifold. While the Inaugural-Dissertation had left the formal determination of space and time to particular spaces and particular times largely unexplained, the first Critique contains the main elements of a theory of the generation of specifically determined plural intuitions out of the unitary and singularprotointuition of space and time. The most detailed treatment of this problem is to be found in the changes (revisions and additions) introduced into the second edition of the first Critique (1787), especially in the Transcendental Deduction of the Categories, although it should be stressed that Kant regarded the changes of the second edition not as substantial corrections but as

48 See $B$ 37/A 22-B 53/A 36. In the first Critique the treatment of space precedes that of time. Accordingly, I will now switch from talking about "time and space" to talking about "space and time." 
improvements in the "manner of presentation" (Darstellungsart) of his doctrine, which remained, in the main, unchanged. ${ }^{49}$

The main reason for Kant's increased interest in the non-sensory features that accrue to intuition, to be found in the first Critique, is the realization, subsequent to the Inaugural-Dissertation and to be dated to the early $1770 s^{50}$ that the pure concepts of the understanding do not actually refer to a world of their own, the world of the understanding, but pertain to the world of sense, of which they constitute the "intelligible form" in addition to its "sensible form" provided by the pure intuitions. ${ }^{51}$ Thus the dualism of worlds, each to be cognized on the basis of its own "form and grounds" (forma et principia), underlying the theory of time and space in the InauguralDissertation, has been replaced in the first Critique by a combination of monistic cosmology (one world to be cognized) and dualistic epistemology (two stems of cognition). ${ }^{52}$ The technical terms and doctrinal concepts employed by Kant to bring out the dual-but-unitary nature of the world of sense and its double constitution through sensible and intelligible forms are "experience" (Erfahrung) and "empirical cognition" (Erfahrungserkenntnis) and, as their object domain, "nature" (Natur)..$^{53}$ As a result of the reassignment of the understanding to the world of sense, reconceived as the domain of "experience" (Erfahrung), Kant now has to maintain the difference between the two key factors entering into the principiation of experience (sensibility and understanding) and their epistemic conveyances (intuition and concept), while also establishing their essential collaboration in the bringing about of experience and its objects. In the former regard, Kant

\footnotetext{
${ }^{49}$ See B XXXVIIff.

${ }^{50}$ Kant's famous letter to Marcus Herz from 21 February 1772 (AA 10: 129-135, esp. 130) documents his awareness of the problem of the objective reference of our concepts of the understanding without indicating the solution. The latter takes shape in the Reflexionen of the so-called "Duisburg'scher Nachlaß" (AA 17: 643-673).
}

${ }^{51}$ See, e.g., Reflexion 4653 (AA 17: 626; approximately 1772): "Our understanding does not give materials by which we could cognize a new world but forms in order to set up the the present one according to them." Unser Verstand giebt nicht materialien, wodurch wir eine neue Welt erkennen könnten, sondern Formen, um die Gegenwärtige darnach einzurichten.)

52 Strictly speaking, the intelligible world of 1770 undergoes a differentiation into the object domain of the understanding in the narrow sense (the power of concepts and rules), coextensive with that of the objects given by sensibility, and the object domain of reason in the narrow sense (the power of ideas and inferences), which is not subject to theoretical cognition but remains a central concern to Kant in moral philosophy in constituting the "moral world" (moralische Welt; B 843/A 815) or the "kingdom of ends" (Reich der Zwecke; AA 4: 433).

${ }^{53}$ See B 126f./A 93f., A 114 and B 163f.; see also AA 4: 294ff. (Prolegomena). 
stresses the complete lack of order among the manifold of intuition and the monopoly of the understanding for the formation of unity among representations of all kinds, regardless of whether they are intuitions or concepts. In the latter regard, he emphasizes the amenability of the unordered manifold of intuition to conceptual ordering.

At the most basic level, the joint venture of the manifold of intuition and the unity of conception manifests itself in the double nature of space and time as forms of intuition and as pure intuitions. In their capacity as universal forms of all sensible intuition, space and time do not yet provide unity to the infinitely varied ("manifold") possible spatio-temporal arrays they contain. As forms of intuition, space and time function merely as the basic ways or modes for sensational intake. Any shaping of space and time into determined regions and stretches of space and time requires, on Kant's analysis, the "comprehension of the manifold" (Zusammenfassung des Manngifaltigen), by means of which the form of intuition becomes the intuition of the form of intuition or "formal intuition." 54 M ore yet, not only the plural, specifically determined spaces and times but also singular space and singular time themselves as all-encompassing, infinite pure intuitions first come about through adding unity, by way of unification, to an originally ununified, sheer ("pure") manifold.

In the first Critique Kant's technical term for the "combination" (Verbindung; conjunctio) of a given manifold, is "synthesis" (Synthesis). ${ }^{55}$ He clearly states that the synthesizing of a manifold is not an accomplishment of sensibility, which is merely passive and incapable of any ordering. Rather he locates the origin of synthesis in an active, shaping power of the human mind. The function for synthesizing cognitive items of all kinds ("representations;" Vorstellungen) is assigned to the "power of the imagination" (Einbildungskraft). ${ }^{56}$ Synthesis "in general" (überhaupt), regardless of further specifications as to what is being synthesized and how, is "a mere effect of the power of the imagination, a blind, although indispensable function of the soul, without which we would have no cognition at all, but of which we are rarely ever conscious." ${ }^{57}$ As the use of the term

\footnotetext{
${ }^{54}$ See B 160f. note. On the difference between "form of intuition" and "formal intuition" in Kant, see my "Comments on Professor Kitcher's 'Connecting Intuitions and Concepts at B 160n.'," The Southern J ournal of Philosophy 25 (1987), Supplement (Spindel Conference 1986: The B-Deduction), 151-155.

55 See B 130.

${ }^{56}$ See B 103/A 78.

${ }^{57}$ B 103/A 78 (my emphasis) (die bloße Wirkung der Einbildungskraft, einer blinden, obgleich unentbehrlichen Funktion der Seele, ohne die wir überall keine Erkenntnis haben würden, der wir uns aber selten nur einmal bewußt sind).
} 
"blind" here suggests, the function of the power of the imagination, considered by itself and without a further function coming in, may enable the formation of cognition but still leaves it at an incomplete stage at which something, which has yet to be identified, is not yet visible and awaits its coming into view due to a further level of formation. To be sure, the stages in the formation of cognition distinguished by Kant should not be taken as diachronically arranged phases in the actual coming about of cognition. Kant's interest in the first Critique is not a psychological interest in the factual genesis of cognition but a logical-normative interest in the universal subjective grounds that render cognition, in principle, possible. ${ }^{58}$ Accordingly, the stages distinguished by Kant in the constitution of cognition should be understood as so many universal moments of a complex dynamical structure the philosophical reconstruction of which may include narrative devices, such as the sequence of beginning, middle and end, without implying a real distinction of the parts involved.

The synthesis attributed by Kant to the power of the imagination consists most basically in the joining of sequentially apprehended stretches of time and regions of space into one ("single") intuition so that the continuous flow of data receives articulation through primary structural features to be designated, in the context of their conceptual reconstruction, by concepts such as "before," after," "to the right of." Thus the power of the imagination lends shape to the manifold of sense by joining it to figures in space and time. Kant terms such a figure an "image" (Bild), drawing on the etymological proximity of "image" and "imagination." ${ }^{59}$ The point of the term is not to claim a likeness of the image in question to something else but to convey the formed or shaped character of the product of the imagination. The function of the imagination that concerns Kant in the first Critique is not the reproduction of preexisting images but the productive function of first bringing the manifold to the formative condition of wholes that are set off from other regions of the manifold of space and time and endowed with a certain coherence provided by the delineation of a region of space or a stretch of time. With regard to space, Kant characterizes the transition from the "pure," undetermined manifold to the determined intuition of parts of space

\footnotetext{
58 The empiricist Humean account of human nature is at the center of the work of Kant's influential contemporary, Nicolaus Tetens, whose Essays on Human Nature (Versuche über die menschliche Natur) Kant kept on his desk while writing the first Critique. On Kant's relation to Tetens, see Reflexion 4900 and Reflexion 4901 (AA 18: 23) and my entries "Tetens, J ohann Nicolaus," Routledge encyclopedia of philosophy, ed. Edward Craig, 10 vols (London: Routledge, 1998), 9: 319-322 and "Tetens, J ohann Nicolaus," Concise Routledge encyclopedia of philosophy, ed. E. Craig (London and New York, 2000), 882f.
}

${ }^{59}$ See A 120. 
as "description of a space" (Beschreibung eines Raumes) ${ }^{60}$, where the term "description" does not designate the recording of a previously existing spatial order but the original inscription of space through which a figure in space first comes about. In order to convey the active nature of the "productive imagination" (produktive Einbildungskraft) ${ }^{61}$, Kant characterizes the "pure act of successive synthesis of the manifold in outer intuition" as "movement qua action of the subject" (Bewegung, als Handlung des Subjekts), to be distinguished from objective movement as the dislocation of an object in space. ${ }^{62}$

In calling the synthesis of the manifold through the power of imagination "blind," Kant draws attention to the incompleteness of the imaginational synthesis as such in the absence of a further level of the mind's active formation of cognition, viz. the understanding. But the latter's contribution does not take the form of some external addition to the already accomplished synthesis of the imagination. On Kant's view, the understanding is always already operative in imaginational synthesis by providing the basic function of unity that guides or orients the synthesis of the manifold. ${ }^{63}$ Accordingly, the power of the imagination occupies a middle position between sensibility and the understanding. In a handwritten marginal emendation in his personal copy of the first edition of the first Critique, Kant replaced the passage, cited earlier and contained in the first and the second edition of the work, about the power of the imagination being a "function of the soul" with the more specific phrase, "a function of the understanding." $64 \mathrm{He}$ further clarifies the double status of the power of the imagination by stressing that, on account of the sensible condition of its operation, it "belongs ... to sensibility" (gehört ... zur Sinnlichkeit), while equally emphasizing that, with regard to the synthesis it effectuates in the pure manifold, the power of the imagination is "an effect of the understanding on sensibility" (eine Wirkung des Verstandes auf die Sinnlichkeit). ${ }^{65}$

\footnotetext{
${ }^{60}$ B $154 f$.

${ }^{61}$ B 154; also A 123.

62 B154f. and 155 note.

${ }^{63}$ See B $151 f$.

${ }^{64}$ The original passage occurs at A 78. For the emendation, see AA 20: 45. The emendation is also noted in all modern editions of the first Critique in German and English.

65 B 151f. Heidegger's Kant interpretation in Kant and Problem of M etaphysics focuses on the separate status of the power of the imagination in the first edition of the first Critique, which Heidegger then radicalizes to the original status of that mental power as the proto-temporal root of subjectivity. Kant himself identifies the "root faculty of all our cognition" (Radikalvermögen aller unsrer Erkenntnis), in the first edition of the first Critique, with the faculty of transcendental apperception (A 114).
} 
Yet the presence of the understanding in imaginational synthesis need not involve already formed concepts. On the contrary, synthetically unified space and time, along with the sensations located at determined spaces and times, first makes possible the formation of concepts. Kant explains that he had introduced space as a pure intuition, and hence as a synthetic whole, on purpose already in the transcendental theory of sensibility (Transcendental Aesthetic), in order to indicate that the pure intuition of space as such precedes all concepts of specific places and shapes in space. $\mathrm{He}$ then points out that the presence of unity in space qua pure intuition, or in "space considered as an object" (der Raum, als Gegenstand vorgestellt), "presupposes a synthesis that does not belong to the senses, but by means of which all concepts of space and time first become possible." 66 The tripartite division indicated here between sheer, unordered manifold of space and time ("form of intuition"), original synthesis of space and time ("formal intuition") and concepts regarding space and time is confirmed by Kant's discussion of "space and time and all their parts" as "intuitions, hence singular representations" (einzelne Vorstellungen) and by the subsequent contrast drawn between the mereological properties of intuitions and those of concepts. ${ }^{67}$ In the case of concepts, the same instance of awareness (e.g., the awareness of the color red) is encountered in many different representations (e.g., the awareness of a red rose or of a red square). In the case of intuitions, each such singular representation contains a manifold "in itself" (in sich) and hence involves "many representations as contained in one ... and hence as composite" (viel Vorstellungen als in einer ... mithin als zusammengesetzt). ${ }^{68}$ The crucial point here is the presence of a composite structure not in the pure manifold of intuition but in intuition qua singular representation. This composite nature of intuition as such exceeds the deliverances of sensibility and its mere forms (pure manifold), but does not yet reflect the presence of concepts, rather enabling their formation.

The synthesis of the imagination exercised, under the guidance of the understanding, on the manifold of the senses yields what Kant terms "appearances" (Erscheinungen). Continuing an ancient philosophical tradition going back to Plato, Kant uses the term to convey the difference between the way things might appear (to someone, under certain conditions, etc.) and the way things are. Most commentators on Kant's adaptation of the distinction between appearance and reality focus on the Kantian

\footnotetext{
${ }^{66}$ B 160f. note (... ob sie zwar eine Synthesis, die nicht den Sinnen angehört, durch welche aber alle Begriffe von Raum und Zeit zuerst möglich werden, voraussetzt.)

${ }^{67}$ See B 136 note.

${ }^{68}$ B 136 note.
} 
distinction between the things as they are in themselves (in short: the things in themselves; Dinge an sich) and their appearances, or the things as they come to be cognized under conditions of human sensibility, i.e., in space and time. While this onto-logical distinction, established in the Transcendental A esthetic of the first Critique, ${ }^{69}$ is indeed the primary contrast underlying Kant's use of technical term "appearance," it is crucial not to overlook a second employment of the term "appearance" which opposes the appearance not to some unknown and unknowable thing that transcends our experience (or to an unknown and unknowable side or aspect of a thing transcending our experience) but to an as-yet unknown but knowable thing (or side of a thing), one that is entirely within the range of our experience. The latter distinction comes into play in the Transcendental A nalytic of the first Critique, when Kant contrasts the way something appears to someone as a function of the particular way in which it is first given in intuition, with the way things might be independent of the varying conditions of sensible intuition, with the specification that the latter way of being is to be ascertained not by recourse to the senses but to the understanding. ${ }^{70}$

To be sure, the epistemo-logical distinction of appearance and object itself must not involve an uncritical relapse into the assumption of a nonsensory, intellectual intuition on the part of "our" understanding. The object which exceeds its varied actual and possible presentations to the senses or "appearances" is not intuited, or grasped directly, but is being thought. M oreover, the object is thought not as existing "in an overheavenly place," as Plato puts it in the Phaedo, and hence ontologically distinct from the appearances, but as belonging to the appearances - as the unifying reference point of the multiple aspects, sides or views under which the object presents itself by means of intuitions. To say of the object that it is thought, as opposed to given, is to say that is a logical construct produced by the understanding on the material basis of given intuitions and serving to unify the latter. In this logical sense, an object can never be given but can only be thought thought along with "its" appearances, and this in a manner not open to whim and fancy but such that it lends invariance and stability to the multitude of correlated appearances. Drawing on Kant's discourse about the manifold of the senses being synthesized into an image, one can regard the object in the logical sense just outlined as that of which the relevant intuitions are images, yet which cannot be captured by any such image, or their sumtotal, but only by the additional intellectual function of referring the intuitions to that of which they are the intuitions.

\footnotetext{
${ }^{69}$ See B42ff./A 26 and B49ff./A $32 \mathrm{ff}$.

70 See B139f.; A A $109 f$.
} 
Kant also calls the object in the strong, logical sense the "transcendental object," 71 thereby indicating that is not a particular object but the universal objectivity function by means of which the variable cognitions of appearances are elevated to the cognition of an object that is invariant in relation to the changing conditions of its appearances. In an alternative formulation of the same thought, Kant refers to the contribution that the understanding makes to the synthesis of the imagination as providing "transcendental content."72 Again, the content in question is not to be understood as some particular content, and certainly not as content provided by the senses, but as that logical feature which no sensible intuition as such can provide and which alone can refer intuitions to their object and transform them from reports about perceptions to warranted claims about objects, i.e., objects of experience. Given the logical, thought-borne nature of objects and of the cognition of objects in Kant, the specific formal contribution that the understanding makes to the cognition of perception-invariant objects cannot consist in the grasp of some preexisting, absolute order of things. Rather the pure concepts of the understanding (categories) formulate the universal subjective conditions under which appearances can be considered appearances of relatively stable, lawfully behaving objects in space and time.

In the absence of such intellectual regularity conditions, appearances would not coalesce into objects. There would be perceptions of unpredictable appearances but no experience of objects that each have a nature and that jointly constitute nature as the sum-total of appearances under laws. ${ }^{73}$ Without the categories regulating the basic order of the appearances, there might even be particular concepts formed to single out and designate features encountered in intuition, such as "red" or "round." But there would be no determinate logical order guiding the attribution of such concepts. If, e. g., the category of substance and accident were lacking, or could not be brought to bear on appearances, then there would be no ascertainable difference between the statement "some circles are red" and the statement "some red is a circle," since the categorial concept of the relation between the bearer of properties and the properties borne would be lacking, or would find no application.

\footnotetext{
${ }^{71}$ A 109.

72 B 105/A 79.

${ }^{73}$ On the scenario of appearances not conforming to the pure concepts and principles of the understanding, see B 123/90f., culminating in the statement: "for intuition is in absolutely no need of the functions of thinking" (denn die Anschauung bedarf der Funktionen des Denkens auf keine Weise). See also the distinction drawn only in the Prolegomena between "judgments of perception" (Wahrnehmungsurteile), which record the appearances in their changing subjective presentations, and "judgments of experience" (Erfahrungsurteile), which determine the empirical object as such (AA 4: 298ff.).
} 
For Kant, applying the "mere form of the understanding" (bloße Verstandesform) in judgments, such as the logical form of a hypothetical judgment ("if ... then"), to some synthesized manifold of space and time leads to the logical articulation of the appearances but does not establish cognitive reference to an object and to the objective order to which it belongs. In order to achieve the latter, the pure concepts of the understanding or the categories have to come, which are the logical forms of judgments employed not as forms for analyzing intuitions (or other already given representations) but as formal determination of the objective features to be synthetically correlated with given intuitions. In Kant's w ords, the categories are "concepts of an object in general through which its intuition is considered as determined with respect to one of the logical functions for judgments." ${ }^{14}$ The point here is that neither the synthesis of the manifold as such nor the logical functions of judging as such lend objective determination to the appearances but leave the object (in the strong, logical sense) undetermined.

Still Kant insists on the proximity, more yet: on the ultimate identity, of the forms of judging and the forms of thinking an object. To be sure, the forms of judging serve to articulate, by means of analysis, the logical structure of a given manifold, while the forms of thinking an object serve to provide an object to given intuitions. Both are employments of the understanding and involve the engagement of the same set of basic unification functions, exercised in specifically different ways on specifically different material. In Kant's words: "The same function which gives unity to the different representations in a judgment also gives unity to the mere synthesis of different representations in an intuition, which (sc. latter unity), expressed universally, is called the pure concept of the understanding."75 McDowell takes this as a statement to the effect that the unity functions of the understanding are already contained in intuition. That would render superfluous the entire enterprise of the Transcendental Deduction of the Categories with its focus on whether and how functions of the understanding have a bearing on intuitions. Kant's point is that categorial unity is not to be found in an intuition but has to be provided to the intuition by the understanding. Considering that the addition of categorial determination to objectively undetermined intuitions is not a matter of temporal sequence but of structural constitution, Kant can also say that categorical unity would have to be given "with" (mit) the intuitions but not "in" (in) them. ${ }^{76}$ But that

\footnotetext{
${ }^{74}$ B 128 (Begriffe von einem Gegenstande, dadurch dessen Anschauung in Ansehung einer der logischen Funktionen zu urteilen als bestimmt angesehen wird.).

${ }^{75}$ B 104f./A 79.

${ }^{76}$ See B 161 for Kant's own contrastive view of the two prepositions.
} 
still leaves open the question, to be addressed in the Deduction, whether it is indeed the case, and how it is possible, that the categories find a hold in the material ("content") provided by intuition.

Hence the blindness that Kant attributes to the workings of the imagination, even to its operation under the clandestine guidance of the understanding ${ }^{77}$ is a blindness with respect to the object to be correlated with given intuitions by means of the categories. In light of this notion of object-blindness, Kant's pronouncement that intuitions without concepts are blind takes on the further, quite specific meaning that without the categorial concepts intuitions are object-blind in that they have no "transcendental object" or "transcendental content" provided to them. One might even say that intuitions lacking "transcendental content" are not only blind but also empty. In a surprising reversal of status, it is not intuition that provides content to the otherwise empty categorial concepts but the categories that provide content in the strong, logical sense to intuitions, which would otherwise be lacking the reference to an object in the strong sense. This is not to deny that, at a surface level, Kant's statement about thoughts without content being empty refers to the ordinary case of concepts first receiving confirmation and validation by means of corresponding sensible intuitions. M ore yet, even the categories, without which intuitions w ould have no "transcendental content," are in turn in need of another kind of content which only intuitions can provide for them and without which they would be empty "forms of thinking" (Gedankenformen). ${ }^{78}$ There are tw o different senses of "content" operative here: the transcendental content (reference to possible empirical objects in space and time) provided to the intuitions by the categories and the sensible, better yet: synthesized imaginational content provided to the categories by pure intuition. (In addition, there is the empirical content provided to empirical concepts by empirical intuition. But the latter is not a primary concern of Kant's in the first Critique, with its focus on the conditions of the possibility of a priori cognition of objects, even if the objects to be cognized a priori turn out to be objects of experience.)

\section{Form and Content}

A closer look at the prehistory and the systematic context of Kant's remark about thoughts being possibly empty and intuitions being possibly blind has shown the exegetical and philosophical problems inherent in

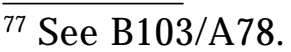

${ }^{78}$ See B150.
} 
M cDowell's reading, which ignores the latter half of the statement and turns its former half into a thesis about the concept-ladenness of intuitions in Kant. By focusing exclusively on the validation of empirical concepts through empirical intuitions, M cDowell has deprived Kant's ingenious remark of much of its philosophical significance, which concerns primarily the mutual completion of pre-conceptual intuitions and post-intuitional concepts. Considering the implicit focus of Kant's remark on the relation between pure intuitions (of space and time) and pure concepts (of the understanding), the content that prevents a thought from being empty cannot be, as M cDow ell would have it, some factual experiential intake. Claims to universality and necessity, as they are implicit in the categories' status as the basic intellectual forms of experience and its objects, cannot be confirmed contingently and by single instances. On Kant's view, the justification of categorial claims cannot have recourse to any given feature of experience. The validation of the categories can only take the form of showing that experience, along with its objects, would not be possible were it not for the contribution made by the categories in determining an object to given intuitions. Hence the validation of the categories does not occur by some actual experience but by what Kant terms "possible experience" (mögliche Erfahrung) or, more precisely, the "possibility of experience" (M öglichkeit der Erfahrung), to be understood as the active, dynamical "rendering possible" (ermöglichen) of experience through those very concepts. ${ }^{79}$ A ccordingly, the specific content that completes the cognitive status of the categories are "possible intuitions." 80

Kant is quite explicit about the disanalogy in the validation procedure of empirical concepts and of categorial concepts. The validation of empirical concepts occurs by citing, in an exemplary manner, the corresponding empirical intuition; by contrast, categorial concepts cannot be instantiated in an intuition to be given, not even in an a priori intuition. ${ }^{81}$ There is no intuition, empirical or pure, to correspond to the category of causality. There is only the universal form of causal thinking through which the temporal sequence of appearances, provided it is found to be irreversible, is taken as involving an objective determination of the order of events. ${ }^{82}$ But no specific cause is thereby identified. Thus the categories are nothing but "rules according to which a certain synthetic unity of that which cannot be

\footnotetext{
$\overline{79}$ See B 126f./A 94

80 See B 747/A 719.

${ }^{81}$ On Kant's account, only mathematical concepts can be exhibited in a priori intuition, in a procedure which Kant terms the "construction" of those concepts. See B 740ff./A713ff.

${ }^{82}$ See B 232ff./A 189ff.
} 
represented in an a priori intuition (of the perceptions) is supposed to be looked for empirically." ${ }^{83}$ Hence the content that serves to validate the categories and the principles derived from them, such as the causal principle, is a formal content, a procedural device by means of which yet to be given actual content is anticipated as to its fit into the categorical structure of the empirical world. ${ }^{84}$ Moreover, even the content correlated to empirical concepts qua concepts is not some particular instantiation by means of a particular empirical intuition. Due its inherent generality (as possibly contained in infinitely many objects), a concept cannot be adequately matched by an intuition (as a singular representation). Empirical concepts, too, have to be understood as rules for the determination of appearances that are yet to be given. Kant uses the term "schema" (Schema) to address the open nature of a concept, due to which it exceeds the correlation with any particular corresponding "image" (Bild) of an empirically intuited object. 85

All this suggest a picture of the relation between concept and intuition in Kant that is quite different from the way McDowell reads Kant's remark about possibly empty thoughts, viz., as calling for the grounding of concepts in empirically given and already conceptually structured intuitions. Kant is a formalist about intuitional and conceptual content and an idealist about the universal forms of intuiting and thinking. ${ }^{86}$ The basis in Kant for the demarcation drawn by M cDowell around the conceptual as the logical space of reasons, at the exclusion of the sensory data belonging to the logical space of causes, is the demarcation of a priori form against any content a posteriori. But rather than reducing the aesthetics of intuition to the logic of concepts,

83 B 748f./A $720 f$.

84 "One can call an anticipation all cognition through which I can cognize and determine a priori that which belongs to empirical cognition." (Man kann alle Erkenntnis, wodurch ich dasjenige, was zur empirischen Erkenntnis gehört, a priori erkennen und bestimmen kanm, eine Antizipation nennen.) (B 208/A 167).

85 "M uch less (sc. than a mathematical concept) does an object of experience or an image thereof ever reach the empirical concept; rather the latter always refers immediately to the schema of the power of the imagination, as a rule of the determination of our intuition according to a certain general concept." Noch viel weniger erreicht ein Gegenstand der Erfahrung oder Bild desselben jemals den emprischen Begriff, sondern dieser bezieht sich jederzeit und mittelbar auf das Schema der Einbildungskraft, als eine Regel der Bestimmung unserer Anschauung, gemäß einem gewissen allgemeinen Begriffe.) (B 180/A 141).

${ }^{86}$ On Kant's self-interpretation of "transcendental idealism" as "formal idealism" see B 519/A 491 note. Kant's formalism in theoretical philosophy is matched by his formalism in moral philosophy (in the specification of formal requirements for the moral status of maxims) and his formalism in aesthetics (in the specification of formal requirements for the aesthetic status of objects). 
as McDowell does, Kant maintains that there are two different but interacting sets of forms by means of which data are taken up into the justificatory structures and processes of cognition: intuitions for the reference to the singular and concepts for the reference to the universal. Moreover, while M cDowell takes both intuition and concept as given or already contained in experience, Kant insists on the active, produced nature of the synthesis and the unity involved in experience.

McDowell believes that the only way to move intuition away from the status of psycho-physical data intake and into the epistemological sphere is its assimilation to the conceptual. In Kant, the space of reasons is not limited to concepts but includes intuition as a mode of cognition sui generis. What distinguishes sensation from intuition in Kant is not the latter's clandestine conceptuality but its having been subject to cognitive form, through which data are taken up as material into the subject's arena of justification. To be sure, the formal cognitive activity countenanced by Kant must be conceived in such a way that it reduces cognition neither to arbitrary fiction nor to a mechanical application of fixed forms to some equally rigid contents. Kant sought to avoid this dual pitfall by subjecting the spontaneity of cognitive formation to the dual constraint of universal norms (cognitions a priori) and contingent material diversity (manifold of sense). From Fichte and Hegel to Husserl and Scheler critics of Kant's formalist conception of cognition in general and of metaphysical cognition in particular have called for a material a priori in various guises: as intellectual intuition, as transcendental hyletics or as objective values. McDowell's bid for conceptual facts is a remote descendant of the refusal to accept the scholastic formula, quoted with approval by Kant, "forma dat esse rei," which he translated as "the being of a thing consists in its form" (in der Form besteht das Wesen der Sache), supplemented by the restrictive clause, "insofar as the being is to be cognized by reason" (sofern dieses durch Vernunft erkannt werden soll). ${ }^{87}$ To want to cognize by reason more than the form of a thing risks overburdening reason and turning it from the source of modest but secure insights into the fountainhead of generous but deceptive disclosures.

\footnotetext{
${ }^{87}$ The phrase is taken from an essay, entitled "On a Recently Adopted Elitist Tone in Philosophy" (Von einem neuerdings erhobenen vornehmen Ton in der Philosophie; 1796), in which Kant responds to the polemical characterization of his account the mind's cognitive capacities as "a formgiving factory" (Formgebungsmanufactur) (AA 8:404).
} 
ZÖLLER, Günter. Sobre pensamentos vazios e intuições cegas. A resposta de Kant a McDowell. Trans/Form/Ação, (São Paulo); v.33(1), 2010, p.63-94.

RESUM O: Esse artigo examina a relação entre intuição e conceito em Kant à luz da posição neokantiana de J ohn M cDowell de que intuições estão conceitualmente "carregadas". [1] O foco é sobre o duplo pronunciamento de Kant, segundo o qual pensamentos sem conteúdo são vazios e intuições sem conceitos são cegas. Mostro que intuições como representações singuares não são casos de introdução passiva de dados, mas o resultado da unificação sintética do múltiplo dado dos sentidos pelo poder da imaginação sob a orientação do entendimento. Contra M cDowell, defendo que a amabilidade das intuições para com a determinação conceitual não é devida a alguma conceitualidade pré-existente, absoluta do real, mas ao "trabalho do sujeito".[2] Num nível mais programático, o presente artigo visa demonstrar as limitações de uma apropriação seletiva de Kant e o potencial filosófico de uma análise mais abrangente e aprofundada de sua obra. A seção 1 aborda o equilíbrio único na filosofia de Kant entre o trabalho com problemas particulares e a orientação em direção a um todo sistemático. A seção 2 descreve a posição de $M$ cDow ell acerca da distinção kantiana entre intuição e conceito no contexto das leituras de Kant por Sellars e Strawson. A seção 3 expõe a reincidência de M cDowell no "mito do dado". A seção 4 propõe uma leitura da filosofia teórica de Kant como uma epistemologia do conhecimento metafísico. A seção 5 detalha a explicação original de Kant sobre a intuição sensível na "Dissertação de 1770". A seção 6 apresenta a transição do múltiplo dos sentidos para a síntese na imaginação e para a unificação por meio das categorias na Crítica da razão pura (nas edições de 1781 e de 1787). A seção 7 aborda o formalismo de Kant na epistemologia e na metafísica.

PALAVRA S-CHAVE : Kant. J ohn McDowell. Intuição. Conceito. Múltiplo. Unificação sintética.

\section{References}

DAVIDSON, Donald. On the very idea of a conceptual scheme. In: . Inquiries into truth and interpretation. Oxford: Clarendon Press, 1984. p. 183-198.

HEGEL, Georg Wilhelm Friedrich. J enaeer kritische schriften. Edited by Hartmut Büchner and Otto Pöggeler. Hamburg: Felix Meiner, 1968.

HEIDEGGER, Martin. Kant und das problem der metaphysik. 4 th enlarged edition. Frankfurt/M.: Vittorio Klostermann, 1973.

KANT'S gesammelte Schriften. Berlin: De Gruyter, 1900-

[1] A Crítica da razão pura será citada pela paginação original da segunda e da primeira edições ["B" e "A", respectivamente], indicada em todas as traduções inglesas modernas da obra. Todas as outras referências às obras de Kant remetem à "Edição da Academia": KANT, Immanuel. Gesammelte Schriften. Hrsg.: Bd. 1-22 Preussische Akademie der Wissenschaften, Bd. 23 Deutsche Akademie der Wissenschaften zu Berlin, ab Bd. 24 A kademie der Wissenschaften zu Göttingen. Berlin 1900ff [doravante: "AA"], sendo que a "Correspondência" [volumes 10 a 13] é citada conforme a segunda edição [1922]. Todas as traduções são minhas.

[2] AA 08: 404; cf. n. 87. 
KANT, Immanuel. Prolegomena to any future metaphysics that will be able to present itself as science. Edited by Günter Zöller. Oxford: Oxford University Press, 2004.

KÖHNKE, Klaus-Christian. Entstehung und Aufstieg des Neukantianismus: die deutsche Universitätsphilosophie zwischen Idealismus und Positivismus. Frankfurt: Suhrkamp, 1986.

LEIBNIZ, G. W. Philosophical essays. Edited by Roger Ariew and Daniel Garber. Indianapolis: Hackett, 1989.

MCDOWELL, J ohn. Mind and world. With a new introduction. Cambridge: Harvard University Press, 1996.

. Having the world in view: Sellars, Kant, and intentionality. The J ournal of Philosophy, v. 95, n. 9, p. 431-491, Sept. 1998.

METAPHYSIK nach der Metaphysik. Die limitative Konzeption der Ersten Philosophie bei Kant. In: GLOY, Karin. Unser Zeitalter - ein postmetaphysiches?. Würzburg: Königshausen und Neumann, 2004. p. 231-243.

RORTY, Richard. Philosophy and the mirror of nature. Princeton: Princeton University Press, 1979.

SELLARS, Wilfrid. Science, perception and reality. New York: The Humanities Press, 1963.

. Science and metaphysics. Variations on kantian themes. New York: The Humanities Press, 1968.

ZÖLLER, Günter. Kant on the generation of metaphysical knowledge. In: OBERER, Hariolf; SEEL, Gerhard (Ed.). Kant: analysen - probleme - kritik. Würzburg: Königshausen und Neumann, 1988. p. 71-90.

. Tetens, J ohann Nicolaus. In: CRAIG, Edward (Ed.). Routledge encyclopedia of philosophy. London: Routledge, 1998. v. 9, p. 319-322.

. Tetens, J ohann Nicolaus. In: CRAIG, Edward (Ed.). Concise Routledge encyclopedia of philosophy. London: Routledge, 2000. $882 \mathrm{f}$.

. Pax kantiana. Kant e la pace perpetua in filosofia. In: RA M ETTA, Gaetano (Ed.). Filosofia e guerra nell'età dell'idealismo Tedesco. Milano: Franco Angeli, 2003. p. 51-64.

. In der Begrenzung zeigt sich der Meister: Der metaphysische Minimalismus der Kritik der reinen Vernunft. In: CHOTAS, J .; KARÁSEK, J ;; STOLZENBERG，J. (Ed.). Metaphysik und Kritik. Interpretationen zur "Transzendentalen Dialektik" der Kritik der reinen Vernunft. Würzburg: Königshausen \& Neumann, 2010. p. 17-31. 